\title{
Editorial
}

\section{June Editorial 2020}

We introduce the issue 49th of the Journal of Economics, Finance and Administrative Science with the articles presented in the English version, according to the requirement of the most prestigious databases.

The first paper, "Model for assessing the quality of marketing-management education", analyses a model that incorporates resource-capability variables linked to learning outcomes for students and the competitive positioning of universities. The article proposes some policies to university marketing teachers in designing high-quality marketingmanagement educational programs and in developing self-diagnostic tools that allow a better performance of the university. The next article, "Dimensions of tax burden: A review on OECD countries", aims to examine how the changes in some macroeconomic indicators affect the tax burden. The authors used a panel data analysis method, based on 34 OECD member states. The results go along the literature of Public Finance related to the burden of the tax and Government attendance. The article "Investigation of optimal inflation targets for 15 major oil-exporting sub-Saharan African countries: A panel threshold estimation" investigates the optimal inflation targets in a panel of 15 major oil-exporting sub-Saharan African countries using annual data over the period 1996-2017. The authors found a threshold-effect level of $14.47 \%$.

"Corporate governance and business innovation among listed Moroccan companies" seeks to clarify the relationship between corporate governance and business innovation. It provides empirical evidence of how different mechanisms of corporate governance affect business innovation within the context of Moroccan equities listed companies. The fifth paper, "Mediating role of adoption of an electronic tax system in the relationship between attitude towards electronic tax system and tax compliance", provides us results of a study that establishes the mediating effect of the adoption of an electronic tax system in the relationship between attitude towards electronic tax system and tax compliance. The authors used evidence from small business enterprises of an African developing country.

Then, the empirical article, "An introduction to Pensionomics", introduces a new concept that examines retirement within a multidisciplinary context. In particular, the overall assessment of pension performance is based on historical analysis, incorporating noneconomic variables with a significant impact on economic growth and social development. The Pension Consistency (PC) Index consists of nine main-variables and 50 sub-variables to identify pension scheme levels.

Also, the paper "Predicting manufacturing employee turnover intentions" provides an analysis of how job satisfaction and job embeddedness could predict employee turnover intent. The results of the multiple regression analysis showed a significant relationship between job satisfaction, job embeddedness, and turnover intent; and that satisfied and committed employees are less likely to plan to leave their employment.

(C) Jorge Guillen Uyen. Published in the Journal of Economics, Finance and Administrative Science. Published by Emerald Publishing Limited. This article is published under the Creative Commons Attribution (CC BY 4.0) license. Anyone may reproduce, distribute, translate and create derivative works of this article (for both commercial and non-commercial purposes), subject to full attribution to the original publication and authors. The full terms of this license may be seen at http:// creativecommons.org/licences/by/4.0/legalcode

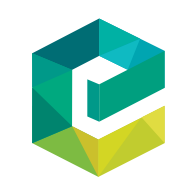

Journal of Economics, Finance and Administrative Science Vol. 25 No. 49, 2020 pp. 3-4 
JEFAS

25,49

4
From the financial analysis, the article "The dynamics of bond market development, stock market development and economic growth: Evidence from the G-20 countries" investigates whether Granger causal relationships exist between bond market development, stock market development, economic growth and two other macroeconomic variables: inflation rate, and real interest rate. The ninth paper is also a financial one: "The associations between stock prices, inflation rates, interest rates are still persistent: Empirical evidence from Stock Duration Model", and examines the effect of both inflation rate and the interest rate on stock prices using quarterly data on non-financial firms listed in DJIA30 and NASDAQ100 for the period 1999-2016. The stock duration model is employed to measure the sensitivity in variations in inflation rates and interest rates on stock prices.

Finally, "Generation and distribution of income in Mexico, 1990-2015" is an article that reviews the efficient use of economic and social resources to generate income, and the same time reduce the concentration of wealth in the 32 states of the Mexican Republic during the period 2000-2010.

The articles attempt to fulfill the main scope of the journal, which is to provide the edge of knowledge in the areas of Business, Economics, Finance, Operations and Marketing.

Jorge Guillen Uyen Universidad ESAN, Lima, Peru 